\title{
Research on Performance Management of Chinese SME
}

\author{
Dong Chen \\ School of Public Management, Southwest University of Economics and Finance \\ Chengdu 610074, China \\ E-mail: pkudodo@126.com
}

Received: January 6, 2011 Accepted: January 31, 2011 doi:10.5539/ijbm.v6n4p263

\begin{abstract}
Human resource plays a key role in economic life, which determines the competitive advantage of one enterprise over another. Performance management, as the core of modern human resource management, is more incentive and guiding than eliminating or promoting employees. Based on discussing the effects of performance management in enterprise operations, this paper analyzes problems in performance management of SME, and advances suggestions for SME carrying out effective performance management.
\end{abstract}

Keywords: Small and medium-sized enterprise (SME), Human resource management, Performance management

\section{Background of the research}

Human resource is the most active factor in economic activity, and also the most important resource. It has a special effect on economic growth, and also important meanings for the survival and development of enterprise. The concept of human resource management appears after Drucker suggesting the concept of human resource in 1954. It develops fast though it does not have a long history. In the past three decades, human resource management experienced two important changes. The first is to become human resource management from general personnel management. The second is to become strategic human resource management from human resource management. Human resource management includes seven aspects: human resource planning, job analysis, recruitment, performance management, compensation management, training and development, and employee relationship management. Here, performance management is the core of whole system.

Although Chinese enterprises have achieved some successes in performance management of human resource, there is still a huge gap, compared to western developed countries. In particular, because of undeveloped theories, low management level, poor quality of staff, and outdated management ideas, Chinese SMEs just mechanically copy and apply some theories of performance management without necessary empirical analysis and resource, exposing many imperfections.

\section{The application of performance management in enterprise strategy}

Performance management is a process in which managers and employees reach a consensus on responsibilities, goals, and how to achieve success, and also a process of strengthening practical management and driving employees to gain excellent performance. As for the basic functions of human resource management, performance management is the core, which connects closely with every ring of human resource management.

First of all, job analysis is an important base for performance management. Job analysis is to establish the job responsibilities of certain position, by which forming key indicators for evaluating the performance of the position. These indicators are standards for evaluating the performance of employees in the position. Job analysis provides the base for the execution of performance management.

Secondly, performance management is an important factor determining the compensation. For different compensation systems and different positions, performance management presents different compensation structures and proportions.

Finally, the most important goal of performance management is to know the advantages and disadvantages of employees' performance in work, and improve the performance. Therefore, training is an important part after performance appraisal. After performance appraisal, managers and employees will make up plans for improving future performances based on self development wills and present performances. 
A scientific performance management system should drive the improvement of organizational and individual performance, and promote the optimization of business process, and guaranteeing the final success of enterprise's strategic objective. Therefore, performance management holds a core position in the two organic systems, namely human resource management and enterprise management. To strengthen performance management has practical significance for improving the management level of whole enterprise.

\section{Problems in performance management of Chinese SMEs}

\subsection{Can not establish performance indicators scientifically}

One vital factor in the process of performance appraisal is to establish indicators, what directly affects the results of performance appraisal. Setting performance indicators scientifically can make the appraisal focus on the target and give employees more guidance. However, facts prove that there are many problems in choosing performance indicators. For example, the establishment of indicators strays away from enterprise's strategic objective, which does not reflect the enterprise's strategic intention correctly. As a result, it fails to direct employees to dedicate to enterprise's strategic objective. As the enterprise makes up indicators of performance appraisal, managers do not communicate with employees effectively and the appraisal includes the personal favors and disfavors of few leaders. The employees just take the appraisal passively, without initiatives and enthusiasm for participation, which is not conductive to apply performance appraisal or realize organizational aims.

\subsection{Can not use the performance appraisal methods skillfully}

During the process of applying performance appraisal, ranking the results is the most common problem. The most popular method is the compulsory distribution. However, in practice the implementation of this method is less desirable. On one hand, because of the low comprehensive quality of managers and their old thoughts, and they are not familiar with performance management system and performance appraisal, they do not follow the compulsory distribution section and distinguish employees with good job performance from ones with bad job performance as they score the performance. On the other hand, in real performance appraisal in an enterprise, it is often the superior who evaluate his or her subordinate. As the direct superior, the manager may prefer to indulge his or her subordinate. Even if the employee's daily performance is normal, the manager may give a high score, ruining the rules and the balance of performance management system.

\subsection{Can not communicate with each other sufficiently during the performance appraisal process}

The attitude of employees to performance management, cooperate or not, affects the implementation of performance appraisal greatly. Performance management is mistaken by employees as a non- confidence of the enterprise. In their eyes, the enterprise uses performance management to restrain and monitor them, punishing them indirectly, and reducing salaries. Therefore, they may produce a sense of resistance toward the implementation of performance management. Without necessary communication between managers and employees, it may lead to misunderstandings between them. In daily work, managers do not record the employees' daily performance. They have no strong support for their scoring employees. As for problems in daily work, causes for these problems, and how to make improvement, employees do not communicate with managers in time and seek for guidance and help.

\subsection{Performance appraisal becomes a mere procedure}

Because of ignorance of managers and limited cooperation of employees, performance appraisal becomes a mere procedure. Many employees regard performance appraisal a formalism from the bottom of heart, going through the procedure annually. Nobody makes careful and objective analysis of performance appraisal, or use the results to help employees analyzes problems in performances, behaviors, abilities, and responsibilities. As a result, some problems occur again and again and nobody makes any change. Employees can not know their disadvantages so that they fail to improve themselves and can not adapt to the needs of enterprise development.

\subsection{Lack of trainings for employees}

This problem is mainly reflected in two aspects. Firstly, the enterprise does not provide systematic trainings for theories of performance management. Some employees think that performance management is only to complete a performance appraisal form. Secondly, the enterprise does not pay sufficient attention to results of performance appraisal. Results of performance appraisal reflect employees' achievements and defects during certain term to some extent. However, the enterprise does not offer relevant trainings for employees in order to update work methods, improve job performance, or help employees achieve successive development.

\section{Suggestions for establishing effective performance management in SMEs}

\subsection{Confirm the enterprise strategic objective}

Enterprise strategic objective is the basic content of enterprise strategy, the pursuit of enterprise carrying out its 
mission, and the further strengthen of enterprise mission in some most important fields. The performance management of human resource should be consistent with enterprise's top-down strategic objective, and also help to improve business process. Only when the enterprise has clear strategic objective, can it decompose strategic objective to each department and position. On this basis, use the tool of performance appraisal to appraise individual performance, and improve performances of employees and enterprise.

\subsection{Set up scientific performance appraisal system}

To determine the performance indicators, we should communicate with employees, ask their views, and invite them to participate into the process, in stead of just delivering decisions from top to bottom. To set up performance indicators, we should reduce subjective and ambiguous contents. It is unnecessary to choose an indicator that seldom associates with work contents. To set up the weights of indicators, we should make practical analyses, and establish the degree of importance of each indicator in the whole indicator system before giving relevant weight, in order to achieve the scientific management of performance appraisal. In this case, the enterprise needs to hold an overall analysis and control over self business philosophy, values, business characteristics, and quality of employees. On this basis, design a performance appraisal system that helps to improve labor productivity, and make decisions of salary raise, promotion, and job transfer, serving the development of enterprise.

\subsection{Choose reasonable and effective incentives}

By means of performance appraisal, find advantage of employees and expose problems, and help employees work better in future. In practice, many enterprises emphasize on the associated incentive of linking compensation with performance appraisal. Besides, they should focus more on other incentives, such as emotional incentive. By means of emotions between superiors and subordinate, between colleagues, enhance the cohesion and solidarity of enterprise. Emotional incentive can achieve better results than material incentive.

\subsection{Strengthen trainings for employees}

Performance management is a scientific and complex management. It involves many aspects: the establishment of enterprise strategic objective, the communication and feedback in the process of implementation, and the use of appraisal results. The quality of managers and employees determines the successiveness and effectiveness of performance management. Chinese enterprises should build a complete training system, cultivate employees' consciousness of trainings, and make scientific plans for trainings. Managers are the backbone of promoting and implementing the system. Employees are direct participants and benefited by trainings. Organize managers and employees to join in trainings of performance management and enrich their knowledge in order to avoid subjective judgments and make performance appraisal system effective.

\section{Conclusion}

In this paper, the author analyzes problems in the system of performance management of human resource in Chinese SMEs and supplies reasonable suggestions. It not only benefits the building of the system of performance management of human resource in Chinese SMEs, but also encourages them to find their own problems as soon as possible, improving self competitiveness, and participating into international competition better. If an enterprise can make best use of performance management in enterprise management, performance management will play an invaluable role in the process of achieving enterprise strategic objective.

\section{References}

Gao, Hang \& Han, Qiaoxia. (2006). On performance management in SME. Northern Economy, No.3. p50.

Li, Jiesi, Guo, Ning \& Shen, Mei. (2000). Research on performance management system strategy in enterprise. Journal of Capital University of Economics and Business, No.1. p57.

Li, Xiaodong. (2005). On performance management of human resource. Pioneering with Science \& Technology Monthly, No.11. p106.

Sun, Jiangpeng. (2008). Analysis of efficiency of employee management in China. Journal of Xinjiang Vocational University, No.26(4). P13.

Zhang, Ling. (2009). Problems and countermeasures for performance management of human resource. Journal of Liaoning Administration College, No.2. p165. 